\title{
Relasi antara Politik Identitas terhadap Proteksi Perdagangan di bawah Pemerintahan Donald Trump
}

\begin{abstract}
M. Chairil Akbar Setiawan ${ }^{*}$, Garcia Krisnando Nathanael Ginting ${ }^{1}$, dan Anwar Ilmar ${ }^{2}$
${ }^{1}$ Jurusan Hubungan Internasional, Universitas Pembangunan Nasional Veteran Jakarta, 12450, Indonesia

${ }^{2}$ Jurusan Ilmu Politik, Universitas Pembangunan Nasional Veteran Jakarta, 12450, Indonesia

\begin{tabular}{l}
\hline \hline Info Artikel \\
\hline Dikirim: Jun 06, 2020 \\
Diterima: Jul 30, 2020 \\
Dipublikasi: Jul 31, 2020 \\
\hline Kata Kunci: \\
Proteksionisme;
\end{tabular}

Koresponden:

\section{Chairil Akbar Setiawan,} Jurusan Hubungan Internasional Universitas Pembangunan Nasional Veteran Jakarta ABSTRAK

Abstract This article seeks to explain the change in US foreign policy in the economy under Donald Trump's administration since 2017. The analysis will be based on the relationship between Identity Politics and Protectionist policies pursued by Trump. Trump's economic policy orientation shows a significant shift compared to some previous governments. The author will use a Qualitative method with the Explanatory analysis model. Protectionism approach becomes Trump's main platform, which is manifested in rejection of the framework of cooperation in the Trans Pacific Partnership (TPP), renegotiation of economic agreements with Canada and Mexico,or the recent tension of having Trade War against China since 2018. Nationalism sentiment, vigilance on the part of foreigners, or the reification of the identity of the United States are considered to be the main elements that have caused Trump to turn away from the global regime of Neoliberalism. The author wants to examine the relationship between Identity Politics and Trump's economic-political platform. The rise of Identity Politics is not a main cause toward Protectionism in the United States. Trump merely harnessed the failure of neoliberal policies from previous administrations by using the rhetoric of nationalism and identity politic.
\end{abstract}

\section{Email:}

mchairilakbars@upnvj.ac.id

Cantuman Sitasi:

Setiawan, M. Chairil Akbar, Garcia Krisnando Nathanael Ginting, dan Anwar Ilmar. 2020. Relasi Antara Politik Identitas Terhadap Proteksi Perdagangan

Pemerintahan Donald Trump. Journal of Political Issues. 2(1); 58-68. Doi: https://doi.org/10.33019/jpi.v2i 1.32

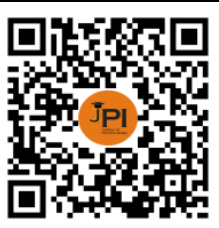

DOI:

https://doi.org/10.33019/jpi.v2i 1.32

Lisensi:

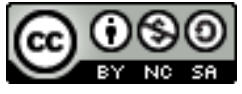

Attribution-NonCommercialShareAlike 4.0 International (CC- BY-NC-SA 4.0)

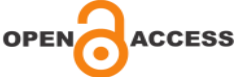

Abstrak Artikel ini berupaya untuk menjelaskan perubahan kebijakan luar negeri Amerika Serikat pada bidang ekonomi dibawah pemerintahan Donald Trump sejak 2017. Analisa akan dilandaskan pada relasi antara Politik Identitas dengan kebijakan Proteksionis yang ditempuh Trump. Orientasi Kebijakan ekonomi Trump menunjukan pergeseran cukup signifikan dibandingkan beberapa pemerintahan sebelumnya. Penulis akan menggunakan metode Kualitatif dengan model analisa Eksplanatoris. Pendekatan Proteksionisme menjadi platform utama Trump, yang termanifetasi pada penolakan atas kerangka kerjasama Trans Pacific Partnership (TPP), renegosiasi kesepakatan ekonomi dengan Kanada dan Meksiko, hingga Perang Dagang terhadap Cina sejak 2018 lalu. Sentiment Nasionalisme, kewaspadaan pada pihak asing, atau reifikasi identitas Amerika Serikat dianggap sebagai unsur utama yang menyebabkan Trump berpaling dari dari rezim global Neoliberalisme. Penulis hendak menguji relasi antara Politik Identitas dengan Platform ekonomi-politik kebijakan Trump tersebut.. Kebangkitan isu Politik Identitas bukanlah penyebab utama yang melahirkan Proteksionisme. Trump hanya memanfaatkan kegagalan kebijakan neoliberal dari pemerintah-pemerintah sebelumnya dengan menggunakan retorika nasionalisme dan politik identitas.

Tentang Penulis:

M. Chairil Akbar Setiawan, Menyelesaikan studi Magister (S2) Jurusan Hubungan Internasional di Universitas Gadjah Mada pada tahun 2015, saat ini penulis adalah Dosen Jurusan Hubungan Internasional di Universitas Pembangunan Nasional Veteran Jakarta.

Garcia Krisnando Nathanael Ginting, Menyelesaikan studi Magister (S2) Jurusan Komunikasi di Sekolah Tinggi Ilmu Komunikasi LSPR pada tahun 2015, saat ini penulis adalah Dosen Jurusan Hubungan Internasional di Universitas Pembangunan Nasional Veteran Jakarta

Anwar Ilmar, Menyelesaikan studi Magister (S2) Jurusan Ilmu Politik di Universitas Indonesia pada tahun 2016, saat ini penulis adalah Dosen Jurusan Ilmu Politik di Universitas Pembangunan Nasional Veteran Jakarta. 


\section{PENDAHULUAN}

Kemenangan Donald Trump menggoncang politik nasional AS dan internasional. Betapa tidak, Trump merontokan semua prediksi dan ekspektasi politik yang menempatkannya sebagai calon medioker (Zucher, 2016). Datang dari latar belakang pebisnis, bintang realityshow, dan sama sekali tak punya pengalaman politik praktis, Trump sukses membalikan keadaan. Sebuah pencapaian yang sensasional mengingat citra buruk yang ia semai selama kampanye. Selain itu, jika dibandingkan dengan Hillary Clinton, ia masih kalah dari segi kapasitas dan pengalaman di bidang pemerintahan. Belum termasuk, keberhasilannya menyingkirkan elit-elit politik partai Republik pada tahap konvensi partai.

Trump membawa platform politik yang cukup berbeda. Ia mengusung wacana Nasionalisme yang bercorak populis. Kepentingan nasional AS yang berkarakter eksklusif wajib menjadi prioritas meskipun harus mengorbankan warisan kebijakan pemerintahanpemerintahan sebelummnya. Hingga 2020 Trump telah melakukan sejumlah perubahan cukup signifikan. Yang paling terasa, sekaligus memicu pro-kontra secara meluas, adalah di sector ekonomi. Trump menarik diri dari blok kerjasama Trans Pacific Patrnership (TPP) yang dirintis Obama, meninjau ulang beberapa kesepakatan dalam NAFTA, keluar dari Paris Agreement tentang reformasi ekonomi atas perubahan iklim, hingga memulai Perang Dagang dengan Cina sejak 2018. Seluruh Langkah itu akan mendorong AS bangkit dan lebih kuat lagi (Lighthizer, 2020). AS dibawah Trump memulai babak baru dalam dinamika ekonomi global.

Fenomena Proteksionisme perdagangan AS adalah salah satu refleksi kebangkitan Populisme Kanan yang mengemuka selama 6 tahun terakhir. Brexit atau keputusan Inggris untuk keluar dari Uni Eropa, terpilihnya Viktor Orban sebagai Perdana Menteri di Hungaria, Narendra Modi menjadi Presiden India, menguatnya partai politik konservatif di Perancis, Jerman, Belanda, atau Poalndia dimaknai sebagai kelahiran kembali politik berbasis identitas. Politik Identitas yang kemudian mewujud pada Populisme ala Trump menjadi salah satu factor penting kemenangannya sebagai presiden AS (Akbar, 2018). Terdapat ketegangan dan hubungan kausal antara politik dengan identitas dalam ranah politik nasional AS.

Populisme Trump diartikulasikan lewat pilihan kebijakan perdagangan yang proteksionis. Model Neoliberalisme dianggap membawa benefit yang lebih besar bagi pihak asing atau lapangan pekerjaan domestic direbut oleh imigran atau pendatang. Trump memandang bahwa warga kulit putih dan kepentingan nasional AS semakin terpinggirkan. Ia berupaya memunculkan kebijakan perdagangan yang nasionalistik dan ekslusif. Partai Demokrat maupun sebagain elit-elit Republik lain Ketika berkuasa membuka ruang yang terlalu besar bagi globalisasi ekonomi. Trump berusaha mengahadirkan kebijakan yang lebih berpihak bagi rakyat Amerika itu sendiri. Oleh karean itu, opsi kebijakan proteksionis perdagangan menjadi kebutuhan objektif dan rasional dalam pemerintahannya.

Artikel ini meyakini bahwa Proteksionisme Perdagangan oleh Trump tidak otomatis mewakili kemenangan populisme kanan atau kembalinya identitas politik sebagai mesin utama yang menggerakan kebijakan ekonomi AS. Proteksinisme Trump akan diletakan sebagai gejala dari fenomena yang lebih luas dan signifikan, yaitu krisis Neoliberalisme di Amerika Serikat, artinya, Proteksionisme hanyalah salah satu aspek saja dari dampak ekonomi yang dihasilkan rezim Neoliberalisme di AS. Sehingga, politik identitas tidak menjadi sumber pokok kebijakan proteksionis melainkan dari kerangka ekonomi-politik. Selain itu, Trump tidak sedang mendorong pergeseran signifikan atas tatanan neoliberal. Hal tersebut akan ditunjukan melalui dua hal. Pertama, Proteksionisme Trump dilakukan sambil menerapkan kebijakan neoliberal pada aspek lain di saat yang bersamaan, dan kedua, Intervensi negara dalam bentuk proteksionisme AS pada prinsipnya adalah manifestasi dari fungsi Negara Neoliberal (Neoliberal State) untuk semakin mengkonsolidasikan ide-ide pasar bebas di luar negeri agar diterapkan oleh negara lain, dalam kasus ini adalah negara-negara yang dianggap merugikan kepentingan ekonomi AS. 
Dengan demikian, pertanyaan penelitian yang hendak dijawab oleh artikel ini adalah pertama Bagaimanakah relasi antara kebijakan proteksionisme Trump dengan kebangkitan populisme politik paska kemenangannya sebagai Presiden 45 Amerika Serikat. Kedua Benarkah politik identitas dan proteksionnisme perdagangan menjadi ekspresi utama perlawanan terhadap Neoliberalisme di Amerika Serikat?

\section{METODE PENELITIAN}

Sebagai pertimbangan untuk mendapatkan hasil investigasi penelitian yang lebih dalam, penelitian ini akan menggunakan "Pendekatan Kualitatif". Sebagaimana yang digambarkan oleh Cassel dan Simon, metode kualitatif merupakan metode penelitian ilmu sosial yang berusaha melakukan deskripsi dan interpretasi secara akurat makna dari gejala yang terjadi dalam konteks sosial. Metode kualitatif menekankan pentingnya penggalian data-data melalui sumber-sumber tertulis dan terucapkan. Harapan dari setiap penelitian kualitatif adalah berusaha untuk mendapatkan data-data menyeluruh tentang situasi yang sedang dipelajari oleh peneliti (Taylor, Bogdan, \& deVault, 2015).

Penelitian ini menggunakan teknik pengumpulan data melalui buku, artikel, jurnal, berita di koran, dokumen resmi serta data lain yang menunjang penelitian ini. Teknik analisis data yang digunakan yaitu reduksi serta triangulasi data yang maan penelitian ini menelusuri tiga pokok variabel yaitu dinamika neoliberalisme di AS, Populisme Trump dan kebijakan perdagangannya, yang kemudian akan diinvestigasi melalui pendekatan ekonomi-politik kritis dan melalui data-data yang diperoleh. terakhir analisis data yang kan menjawab bagaimana dari sejumlah data yang diolah dan diinterpretasikan yang bermuara pada hipotesis untuk menjawab rumusan masalah dalam penelitian ini.

\section{HASIL PENELITIAN DAN PEMBAHASAN}

\section{Proteksionisme Perdagangan Trump dan Neoliberalisme}

Dalam situasi ekonomi dan mosi tidak percaya pada kelompok politik mapan, Trump muncul membawa alternatif. Kekuasaan Trump setidaknya merefleksikan 2 kemungkinan atas pergeseran structural baik bagi Amerika Serikat maupun pada ranah global. Pertama, secara ekonomi-politik, naiknya Trump boleh jadi menunjukan kekalahan rezim pasar bebas dan visi ekonomi neoliberal yang selama ini menjadi kerangka utama kebijakan ekonomi Amerika Serikat. Hal ini berkaitan langsung dengan janji kampanye serta haluan kebijakan yang mulai terlihat di awal masa kepresidenannya. Kedua, secara politik Trump membuka ruang kebangkitan bagi populisme politik konservatif. Isu-isu yang bertautan dengan aspek etnisitas, nasionalisme, gender, hingga agama belakangan muncul sebagai diskursus publik yang cukup ramai. Trump sendiri dianggap berhasil memanfaatkan kekecewaan kelas pekerja kulit putih dan sentiment nasionalisme yang dalam pandangannya digerus oleh platform politik kubu Demokrat (Reich, 2016).

Pegeseran kebijakan luar negeri Trump oleh banyak pihak diyakini sebagai kembalinya bentuk Nasionalisme Ekonomi atau Proteksionisme. AS secara perlahan mulai meninggalkan visi ekonomi pasar bebas (Free Market) yang bercorak Neoliberal. Dominasi pendekatan Neoliberalisme dalam ekonomi global merupakan salah satu instrument hegemoni AS selama 40 tahun terakhir (Dumenil \& Levy, 2011). Kebijakan ekonomi seperti Liberalisasi dan Deregulasi pasar adalah basis perekonomian AS sekaligus hal yang terus dipromosikan kepada negara-negara lain dalam banyak institusi dan perjanjian internasional. Bagi Trump Neoliberalisme, terutama dalam skema Perdagangan internasional AS, justru bersifat kontraproduktif. Sebagian kesepakatan dagang (Trade Deal) lebih sering menggerogoti ekonomi nasional AS (The Economist, 2016). Reformasi yang dilancarkan Trump berupaya menarik garis dari visi Neoliberalisme. 
Selama kurang lebih 3 tahun (2017-2020) Trump telah mengimplementasikan perubahan kebijakan perdagangan. Kesepakatan dagang AS misalnya dalam aspek tarif, ekspor, maupun investasi cenderung bersifat proteksionis. Mitra dagang seperti Korea Selatan, Meksiko, Kanada ,Brazil, Cina, bahkan Uni Eropa didorong untuk beradaptasi terhadap kesepakatan baru dari AS (BBC, 2020). Meskipun tidak berlaku untuk semua jenis komoditas, Trump telah mengimplementasikan paket kebijakan perdagangan yang cukup serius. Pada Januari 2017 AS secara resmi menarik diri dari kerangka Kerjasama multilateral Trans Pacific Partnership (TPP) yang dirintis sejak 2015 oleh Presiden Obama (USTR, 2017). Hal tersebut terasa sangat mengejutkan bagi banyak mitra dagang AS. Di saat bersamaan, Trump dianggap sengaja membuat kemunduran bagi agenda perluasan Perdagangan Bebas.

Langkah paling dramatis adalah Trade War atau Perang Dagang terhadap Cina sejak 2018. Perang tariff antar kedua negara tersebut telah berlangsung kurang lebih 2 tahun. Kantor Khusus bidang Perdagangan AS (USTR, 2017) mengumumkan kebijakan tarif baru bagi sejumlah komoditas yang diimpor dari Cina. Hal tersebut dilakukan sebagai balasan atas tindakan perdagangan tidak adil Cina terhadap AS selama bertahun-tahun. Trump menaikan tarif hingga 25\% untuk baja dan 10\% untuk alumunium dari Cina. Selanjutnya pada Agustus 2018 impor Cina senilai 16 miliar dollar AS harus membayar tarif baru yang naik sebesar 25\% (Amadeo, 2019). Ekonomi AS terutama pada sector perdagangan memang mengalami deficit. Trump memahami deficit perdagangan ini sebagai konsekuensi logis dari skema perdagangan bebas. Deficit perdagangan AS terhadap Cina sebesar 346 miliar dollar atau lebih dari setengah total deficit perdagangan AS yakni 611 miliar dollar (US Census Bereau, 2020). Artinya, Cina menikmati keuntungan yang sangat besar atas pasar di AS. Negara seperti Meksiko, Jepang, dan Jerman juga menjadi terget kebiajakan tarif baru dari pemerintahan Trump karena perdagangan AS terhadap ketiga negara ini ikut mengalami deficit.

Pencapaian negative perdagangan AS berdampak pada menurunnya daya saing industry nasional dan sector ketenagakerjaan di AS. Lapangan pekerjaan adalah yang paling terasa. Kebangkitan luar biasa ekonomi Cina dan sejak tergabung dalam WTO pada 2001, berkontribusi pada pekerjaan yang hilang di AS. Pertumbuhan import yang signifikan dari Cina antara 1999 sampai 2011 mengakibatkan hilangnya sekitar 2,4 juta pekerjaan, 985 ribu diantarnya berasal dari sector manufaktur (Schneider-Petsinger,2017; Rahayu, 2020).

. Kritik Trump pada pada dasarnya lebih banyak diarahkan pada pihak asing sebagai sumber utama masalah ekonomi AS. Trump memandang bahwa negara lain telah bertindak curang dalam sejumlah kesepakatan dagang. Uni Eropa dan Cina memberikan dukungan fiscal dan moneter bagi sejumlah sector strategis ekonominya sehingga komoditas mereka lebih kompetitif dan menguasai pasar AS. Trump secara politik menempatkan AS sebagai target empuk yang mudah didominasi pihak asing. Retorika Trump mewujud pada kepentingan nasional AS yang terus digerogoti. AS tak lagi menjadi negara yang disegani akibat kekalahan dalam arena perdagangan internasional. Dengan demikian, Trump meyakini bahwa AS sedang dikepung oleh pihak eksternal. Disaat yang bersamaan, ia menyoroti kelemahan pemerintahan dan rezim politik AS sebelum pemerintahannya ynag justru tidak berbuat apa-apa.

Inkompetensi kelompok Status Quo, baik dari kubu Demokrat maupun Republik, merupakan modal terbesar dari Trump. Pada 2008, Amerika Serikat ditimpa Krisis Finasial luar biasa yang kemudian menghasilkan resesi ekonomi global pada tahun-tahun selanjutnya. Krisis yang berawal dari kredit perumahan bagi rakyat miskin (Subprime Mortgage) ini dianggap sebagai pukulan menyakitkan terhadap kebijakan deregulasi finansial di AS. Selain itu, Trump banyak menyoroti dana 2 triliun dollar yang dihabiskan untuk biaya perang di Afghanistan dan Irak (Peltier, 2020). AS dalam diplomasi ekonominya diyakini terlalu lunak dan permisif. Kesepakatan Dagang dengan Cina dan Jepang memberi keuntungan terlalu besar bagi kedua negara tersebut dibanding kepentingan nasional. Arus imigran terus terjadi 
akibat control perbatasan dan larangan yang sangat minim (Time, 2016). Semua kebijakan ini dipandang melemahkan posisi ekonomi dan politik AS. Maka,tidaklah mengherankan apabila slogan kampanye Trump berbunyi "Make America Great Again". Identitas politik kini tampil sebagai motor utama yang menggerakan politik dan ekonomi AS.

Inglehart dan Norris, menemukan bahwa kebangkitan Politik Identitas melalui Populisme Kanan secara objektif mampu mengancam dominasi kelompok-kelompok liberal di beberapa negara barat terkemuka. Studi kasus yang mereka ambil adalah strategi politik Trump pada pilpres AS 2016. Mereka meyakini bahwa gerakan populisme kanan sebagian besar ditopang oleh factor kebudayaan (Inglehart \& Norris, 2016). Elemen-elemen seperti nasionalisme, kebanggaan kulit putih, hingga sikap anti imigran dianggap memegang peran kunci. Terjadi transformasi nilai dimana universalisasi demokrasi liberal dipaksa berhadapan dengan sudut pandang identitas cultural yang sifatnya lebih internal. Hipotesa ini diperoleh melalui studi komparasi antara beberapa kelompok populis di sejumlah negara Eropa dan AS itu sendiri. Transformasi ekonomi dan pergeseran-persegeran didalamnya disimpukan tidak menjadi penyebab semakin membesarnya ideologisasi politik kanan.

Populisme Trump, maupun yang terjadi di Eropa, saat ini tidak bisa dijelaskan dengan landasan ekonomi murni tapi sebagian besar sebagai respon untuk melawan perubahan kebudayaan yang progresif. Perubahan tersebut mencakup nilai seperti multikulturalisme, kesetaraan gender, gerakan lingkungan maupun perlindungan hak asasi manusia (Inglehart \& Norris, 2016). Mereka dianggap sebagai ancaman dan bahaya yang nyata bagi keberlangsungan nasionalisme, komunitas local, dan norma lama kebudayaan.

Trump menerjemahkan ancaman terhadap nasionalisme dalam bentuk kebijakan proteksionisme. Supremasi dan kepentingan nasional AS kemudian diadvokasi melalui proteksi sector perdagangan dari arus impor negara lain. Artinya, Trump menafsirkan identitas politik sebagai basis dari kebijakan perdagangannya yang proteksionis. Dengan demikian, masalah ekonomi AS muncul karena prinsip nasionalisme yang terus dikesampingkan demi rezim pasar bebas. Berbagai kesepakatan dan kemitraan ala pasar bebas merupakan "antitesa" dari identitas AS yang nasionalis dan eksklusif. Pada konteks ini, Trump sesungguhnya tidak sedang melawan rezim Neoliberalisme,ali-alih menawarkan alternative kebijakan ekonomi baru.

Populisme merupakan serangkaian imajinasi politik moralistic tertentu yang disandarkan pada konflik antara "rakyat" melawan elit yang dianggap korup atau memiliki moralitas yang inferior (Muller, 2016). Antagonisme antara rakyat dengan elit diperantarai oleh system nilai tertentu, moralitas. Analisa populis tidak banyak atau bahkan tidak bersumber dari kegagalan yang bersifat institusionalis dan structural. Trump sejak awal mengkritik lawan-lawan politiknya pada factor individualistic. Baik itu mentalitas permisif, korup, atau lemah. Kekalahan AS dalam perdagangan internasional bagi Trump adalah representasi dari kemunduran mentalitas para elit. Baginya AS harus berani dan tegas terhadap Cina, Uni Eropa, atau Jepang

\section{Dalih Proteksionisme Perdagangan dan Neoliberalisme Trump}

Trump memakai retorika populisme untuk memobilisasi simpati dan dukungan rakyat kelas bawah yang dirugikan namun tanpa berusaha merubah relasi kuasa yang ada. Posisi istimewa golongan elit ekonomi AS tetap terpelihara. Proteksionisme perdagangan dan sentiment nasionalis yang sering ia lontarkan hanya berfungsi sebagai kamuflase. Kebijakan dan rezim neoliberal di AS masih bertahan tapi dengan kemasan baru. Trump menawarkan apa yang disebut sebagai National Neoliberalism atau Neoliberalisme dengan karakter "nasionalis" (Bush, 2016). Hal tersebut dapat ditunjukan penulis melalui 2 hal yakni,pertama, kesepakatan Perdagangan Bebas bukanlah factor terbesar dari tingkat kesejahteraan rakyat AS yang menurun, dan kedua, Proteksi Perdagangan Trump adalah manifestasi dari penggunaan kekuasaan (power) negara untuk memelihara dominasi neoliberalisme itu sendiri. Kedua 
factor ini akan dianalisis dengan konsep Negara Neoliberal (Neoliberal State) yang terutama dikembangkan oleh David Harvey.

Trump meyakini bahwa lapangan pekerjaan dan tingkat kesejahteraan AS melemah akibat konsensus perdagangan yang buruk. Pada derajat tertentu klaim ini tidak sepenuhnya benar. Hanya menggunakan aspek Deficit perdagangan AS dan relasinya terhadap tingkat kesejahteraan umum dapat menyesatkan. Terdapat factor lain yang lebih krusial dan signifikan. Kebijakan makroekonomi AS yang mempengaruhi jumlah tabungan domestic (domestic saving) dan investasi dalam negeri merupakan peneyebab utamanya (Freund, 2017). Deficit perdagangan AS terjadi karena rakyat AS melakukan belanja atau pengeluaran lebih besar dari pada pendapatannya. Menurut Freund rumah tangga, perusahaan, dan pemerintah AS pada 2015 menghasilkan 16,9 triliun dollar AS dan membelanjakan 17,4 triliun dollar AS, yang berakibat pada deficit 500 miliar dollar AS. Oleh karena itu, deficit perdagangan dapat dibaca sebagai kesalahan dan kelemahan dari kebijakan makroekonomi AS, bukan akibat kesepakatan dagang yang tidak adil (Freund, 2017).

Tingkat kesejahteraan rakyat AS yang terus melemah pada dasarnya tidak direproduksi oleh deficit perdagangan tapi kebijakan fiscal pemerintah AS. Selama 30 tahun lebih AS mengadopsi kebijakan-kebijak berbasis deregulasi dan liberalisasi yang berdampak secara langsung terhadap pendapatan rakyat AS terutama kelas menengah dan bawah. . Pengurangan upah pekerja di AS telah berlangsung terutama sejak 1973, atau pada decade yang sama ketika neoliberalisme tampil sebagai kiblat ekonomi AS. Dari 1973 sampai 1998 produktifitas pekerja tumbuh 46,5\% sementara upah turun rata-rata 8\% (Harman, 2010). Baik faksi Republik maupun Demokrat tampak tidak mampu menyelesaikan kecilnya upah pekerja di Amerika Serikat jika dibandingkan dengan upah di beberapa negara maju lain. Upah minimum hampir tidak berubah selama 9 tahun, dari september 1997 sampai juli 2007 yakni dari 5,15 US Dollar ke 5,85 US Dollar per jam. Di lain pihak biaya hidup meningkat sekitar 25\% dalam periode yang sama. Apabila dikurangi dengan inflasi maka tingkat upah ini adalah yang paling rendah sejak 1955 (Scipes, 2009). Kebijakan upah di AS terlalu longgar dan menguntungkan pemodal atau korporasi. Langkah ini adalah produk dari reformasi ekonomi yang dilancarkan presiden Ronald Reagan sejak 1980-an sekaligus mengakhir model Welfare State yang dijalankan AS sejak 1945 hingga decade 1970-an (Gindin \& Panitch, 2012).

Distribusi kesejahteraan yang buruk dalam ekonomi AS bahkan telah sampai pada tahap yang sangat mengkhawatirkan. Ketimpangan (Inequality) ekonomi adalah masalah besar yang merefleksikan posisi kekuasaan yang tidak seimbang dalam formasi social. Hal tersebut dapat terjadi akibat platform ekonomi yang memberikan ruang akumulasi profit sedemikian luas bagi segelintir elit ekonomi atau korporasi. 1\% populasi memiliki 35,6\% seluruh kekayaan sector swasta atau lebih banyak dari seluruh kekayaan 95\% populasi di AS atau 400 individu terkaya versi Forbes mempunya jumlah kekayaan yang lebih tinggi dibanding 150 juta rakyat AS (Collins, 2012). Kondisi yang sangat paradoks dengan status AS sebagai salah satu negara paling Makmur di dunia. Pendapatan rata-rata rumah tangga di AS, setelah disesuaikan dengan inflasi, pada 2017 ternyata lebih rendah dibanding pada tahun 1989 (Gantz, 2017). Oleh karena itu, kebijakan proteksi perdagangan tidak akan dapat menyelesaikan masalah tingkat kesejahteraan umum rakyat AS beserta ketimpangan ekonomi yang ada. Rendahnya tabungan domestic adalah implikasi langsung dari tren upah yang stagnan atau turun. Hal ini juga berkontribusi pada kenaikan jumlah hutang rumah tangga di AS. Reformasi kebijakan makroekonomi dengan demikian adalah opsi terbaik untuk mengatasi masalah tabungan domestic atau upah rendah.

Tindakan perdagangan negara lain yang dianggap curang hanya menjadi dalih. Trump sedari awal tidak berniat mendorong redistribusi pendapatan yang dikuasai oleh oligarki ekonomi AS. Sejumlah MNC atau Korporasi Multinasional AS seperti General Electric, Caterpillar, Wal-Mart, Chevron, Intel, atau Merck mengurangi sekitar 2,9 juta 
pekerja di AS lalu memindahkan sekitar 2,4 juta pekerja ke luar negeri atau Outsourcing (Jilani,2011). Fenomena ini terjadi akibat motif efisiensi biaya produksi lewat pencarian upah murah dan pajak yang fleksibel. Lapangan pekerjaan justru tidak digerus oleh kebijakan perdagangan negara lain melainkan oleh Tindakan korporasi AS itu sendiri. Bahkan trend outsourcing pekerjaan oleh MNC dari AS belum akan menunjukan trend berkurang di tahuntahun yang akan datang ((Nickles\&Schieberl, 2014). Populisme kanan oleh karenanya dapat menghadirkan dua aspek yakni mobilisasi dukungan "massa" yang terpinggirkan melalui persuasi identitas sekaligus memelihara status quo kelas berkuasa di ranah ekonomi.

Perdagangan internasional AS memang mengalami trend negative pada sector barang atau manufaktur. Namun begitu, pada sector Jasa (service) AS telah menikmati surplus besar. Biro Statistik nasional AS mencatat bahwa AS sukses mengekspor komoditas jasa senilai 845,2 miliar dollar dan mengimpor sebesar 595,4 miliar dollar. Surplus yang ada adalah sekitar 250 miliar dollar pada bidang seperti Hak Kekayaan Intelektual, Royalti, Lisensi, jasa Traveling, jasa computer dan sector finansial (US Census Bureau, 2020). Fakta ini merefleksikan bahwa AS justru diuntungkan oleh arus perdagangan bebas. Globalisasi menyediakan jejaring dan pasar bagi produk-produk korporasi AS ke seluruh dunia. Dengan kata lain, kritik trump bersifat parsial dan tidak objektif terhadap perdagangan bebas. Trump sengaja menyaring fakta dan kasus hanya di sector manufaktur namun disaat yang bersamaan menikmati dominasi sector jasa AS dalam ekonomi dunia. Jika Trump konsisten dengan proteksionisme maka ia, secara logis, akan turut meninjau perdagangan AS di sector jasa. Nyatanya, hal tersebut tidak terjadi.

Secara historis, kebijakan perdagangan yang protekksionis bukanlah hal baru dalam kebijakan luar negeri ekonomi AS. Semangat melindungi ekonomi -domestik yang digaungkan Trump terlebih dahulu mengemuka di era presiden Ronald Reagen. Terjadi debat akademik dan legislative yang cukup alot pada decade 1980-an di AS mengenai strategi Industrial Policy atau kebijakan industry nasional yang dikoordinasikan oleh dukungan pemerintah (Tassinari, 2019). Strategi yang sering disebut sebagai model Developmentalisme ini diimplementasikan secara sukses oleh negara-negara Asia Timur, terutama Jepang (Gilpin, 2001). AS pada masa itu terhimpit oleh serbuan eskpor otomotif dan semikonduktor dari Jepang. Industry nasional AS bersaing dengan produk asal Jepang yang akhirnya mendorong sejumlah proposal untuk mengkaji pelaksanaan kebijakan Industrial Policy. Ketika neraca perdagangan AS defisit terhadap Jepang, pada 1985 Reagen memulai serangkaian perundingan bilateral dengan Jepang, melalui Market-Oriented Selective Market (MOSS). Pemerintah AS mendesak Jepang untuk meliberalisasi pasar dmomestiknya untuk produk AS di sector produk kehutanan, telekomunikasi, elektronik dan farmasi. Yang paling provokatif adalah di sector Semikonduktor dimana AS meminta Jepang menyediakan 20\% pasar domestiknya untuk AS. Desakan AS tersebut tidak mendapat respon postif yang kemudian memicu pemerintahan Reagan memberlakukan kenaikan tarif $100 \%$ untuk 300 juta dollar produk Semokonduktor Jepang yang diekspor ke AS (Wraight, 2019). Artinya, suatu negara dapat bertindak proteksionis untuk memaksa negara lain membuka atau meliberalisasi pasar domestiknya.

Bahkan di era pemerintahan Obama, sejak 2009 AS telah menerapkan kenaikan tarif terhadap import produk ban dan panel matahari dari Cina. Di forum WTO pihak AS aktif menyoroti kebijakan subsidi pemerintah Cina untuk sector otomotifnya (Balaam \& Dilman, 2015). Apa yang dperlihatkan oleh Trump sekarang pada akhirnya adalah repetisi. Trump secara ideologis maupun praksis tidak banyak berbeda dengan pemerintahan sebelumnya. AS yang menganut Neoliberalisme pada derajat tertentu juga melakukan proteksionisme. Mempertentangkan globalisasi dan nasionalisme justru mengaburkan dominasi kapitalisme global. Ekonomi pasar bebas dapat terus eksis dan makin maksimal dengan intervensi pemerintah. Negara pada konteks ini menjadi fungsi bagi proses akumulasi kapitalisme 
neoliberal AS. Oleh karena itu, Tindakan proteksionis Trump merupakan bentuk lain untuk memelihara hegemoni neoliberalisme AS dalam ekonomi dunia.

Disinilah konsep Negara Neoliberal menjadi lebih relevan. Harvey menyimpulkan bahwa Neoliberalisme dapat bekerja baik dalam konteks privat maupun public. Neoliberalimse menurutnya adalah upaya restorai politik kelas dan pendisiplinan kelas pekerja melalui bantuan negara. Neoliberalisme perlu dipahami secara dialektis. Pasar dan negara bukanlah oposisi biner. Menarik garis tegas diantara keduanya tak akan dapat menjawab mengapa pasar selalu dapat melakukan ekspansi baik dalam konteks liberalism maupun langkah interventif negara. Struktur dan institusi social dapat direkayasa untuk mempermulus kebutuhan pasar. Penetrasi kapitalisme bergerak bukan hanya di wilayah ekonomi namun juga pada wilayah moral, intelektual, dan kebudayaan. Peran Negara adalah menciptakan dan memelihara kerangka yang tepat untuk pelaksanaan kebebasan pasar. Negara harus menjamin kualitas dan integritas uang, serta mengatur militer, pertahanan, polisi serta struktur-struktur legal lainnya untuk memenuhi fungsi yang diperlukan untuk menjaga hak kepemilikan, dan apabila perlu menggunakan kekuatan koersif untuk menjamin fungsi pasar (Harvey, 2007).

Proteksi perdagangan Trump dapat dipahami sebagai krisis Neoliberalisme di AS. Sentiment nasionalis, rasisme, dan sikap anti imigran dibawah Trump hanya menjadi gejala di permukaan, bukan sebagai masalah mendasarnya. Euphoria akan nasionalisme tidak menopang keberhasilan Trump melainkan factor kegagalan neoliberalisme yang telah ditempuh sejak decade 1980-an. Formulasi kebijakan luar negeri AS di bidang ekonomi tidak bisa lepas dari pengaruh actor-aktor ekonomi berkuasa domestic. Aliansi dan sentralitas para pemimpin kelas bisnis sangat menonjol dalam pemilihan kebijakan luar negeri ekonomi sejak akhir abad 19 (Gowan \& Stokes, 2012) Kontradiksi kapitalisme di AS, melalui orientasi Neoliberalismenya, membuka ruang bagi kemunculan isu berbasis identitas yang sectarian. Populisme Kanan berperan sebagai kamuflase yang menyembunyikan masalah-masalah ekonomi-politik. Oleh karena itu, platform politik Trump merupakan fenomena yang tidak dapat dipisahkan dari akar ekonomi-politik. Demokrat dan Republik pada prinsipnya adalah 2 sisi dari koin yang sama. Trump adalah seorang miliuner yang tidak disukai oleh kaum mapan di Demokrat bahkan Republik, namun Ketika ia berkuasa maka status quo yang sama masih akan memegang kendali. Seseorang bisa saja melawan Goldman Sach selama kampanye tapi ketika ia berkuasa Glodman Sachs tetap akan memiliki kuasa dalam ekonomi (Lydon, 2017)

\section{SIMPULAN}

Trump telah memperlihatkan bahwa arus Proteksionisme perdagangan kini mulai bergerak. Ekonomi dunia boleh jadi akan meninggalkan model neoliberal yang mengandalkan aliran barang dan kapital yang terliberalisasi. Pada konteks ini, Globalisasi ekonomi dunia memudar. Kerjasama antar negara akan dibayangi oleh konflik-konflik kepentingan nasional antar negara. Namun begitu, Penulis telah menunjukan bahwa relasi antara politik identitas terhadap kebijakan perdagangan proteksionis dibawah Trump sangatlah minim. Pertama, kebijakan proteksionis Trump tidak berkorelasi secara signifikan dengan upaya meningkatkan kesejahteraan rakyat AS. Defisit perdagangan tidak menjadi masalah pokok ekonomi AS tapi lebih pada kebijakan makroekonomi AS yang sangat neoliberal. Kedua, Proteksionisme perdagangan adalah instrument Trump untuk memaksa negara lain untuk meliberalisasi pasar domestiknya. Artinya, kekuasaan negara dimanfaatkan untuk memuluskan agenda perluasan pasar bebas ala neoliberal. Pada konteks tersebut, peran Negara Neoliberal menjadi sentral. Oleh karena itu, Trump tidak sedang melawan arus neoliberalisme lewat slogan ekonominya yang nasionalis. Trump hanya memanfaatkan sentiment nasionalis . kebijakan proteksionis Trump secara dialektis adalah bentuk lain dari upaya memelihara neoliberalisme AS. 


\section{DAFTAR PUSTAKA}

Akbar, M. C., Nugroho, A. Y., \& Kusuma, A. J. (2018). Relation Between Neoliberalism and the Rise of Right Wing Populism in United States After Donald Trump Victory. Advanced Science Letters, 24(5), 3409-3413. Doi: https://doi.org/10.1166/asl.2018.11391

Amadeo, K. (2019, December 7). Why Trade Wars Are Bad and Nobody Wins. Retrieved May 02, 2020, from The Balance. https://www.thebalance.com/trade-wars-definitionhow-it-affects-you-4159973

Balaam, David N, \& Dilman, Bradford (2014). Introduction To International Political Economy. New Jersey: Pearson Education, Inc.

BBC News. (2020, January 19). What has Donald Trump actually achieved on trade? Retrieved May 05, 2020, from BBC News: https://www.bbc.com/news/business-51055491

Bush, S. B. (2016, December 24). Trump and National Neoliberalism. Retrieved May 05, 2020, from Common Dreams. https://www.commondreams.org/views/2016/12/24/trump-and-national-neoliberalism

Collins, Chuck. (2012). 99 To 1 : How Wealth Inequality Is Wrecking the World and What We Can Do About It. San Francisco: Berret Koehlers Publishers.

Dumenil, Gerard, and Levy, Dominique. (2011). The Crisis of Neoliberalism. London: Oxford University Press

Freund, C. (2017, July 7). The Trump administration's misguided focus on trade barriers. Retrieved May 05, 2020, from VOX, CEPR Policy Portal. https://voxeu.org/article/trump-administrations-misguided-focus-trade-barriers

Gantz, Jeremy. (2017). The Age of Inequality : Corporate America's War on Working people. New York: Verso.

Gindin, Sam,\& Panitch, Leo (2012). The Making Of Global Capitalism; the Political Economy of American Empire. New York: Verso

Gilpin, Robert. (2001). Global Political Economy : Understanding International Economic Order. New York: Princeton Universit Press.

Gowan, Peter \& Stokes. (2012). Douglas. Global Economy, in US Foreign Policy. edited by Cox, Michael, \& Stokes, Doug. New York: Oxford Univesity Press.

Harman, C. (2010). Zombie Capitalism: Global crisis and the relevance of Marx. London: Haymarket Books.

Harvey, D. (2007). A brief history of neoliberalism. New York: Oxford University Press.

Inglehart, R. F., \& Norris, P. (2016, August). Trump, Brexit, and the rise of populism: Economic have-nots and cultural backlash. Retrieved May 05, 2020, from research.hks.harvard.edu:

https://research.hks.harvard.edu/publications/getFile.aspx? $\mathrm{Id}=1401$

Jilani, Z. (2011, April 19). CHART: Top 'U.S.' Corporations Outsourced More Than 2.4 Million American Jobs Over The Last Decade. Retrieved May 08, 2020, from Think Progress. https://archive.thinkprogress.org/chart-top-u-s-corporations-outsourcedmore-than-2-4-million-american-jobs-over-the-last-decade-2ea66dfc0e35/ 
Lighthizer, R. E. (2020, July 23). Trump's Trade Policy Is Making America Stronger. Retrieved May 05, 2020, from Foreign Affairs. https://www.foreignaffairs.com/articles/china/2020-07-20/trumps-trade-policymaking-america-stronger

Lydon, C. (2017, June 5). Noam Chomsky: Neoliberalism Is Destroying Our Democracy. May 05, 2020, from The Nation. https://www.thenation.com/article/archive/noamchomsky-neoliberalism-destroying-democracy/

Muller, Jan-Werner (2016). What Is Populism ?. Philladelphia: University of Pensylvania Press.

Nickles, Marshall \& Schieberl, Jeffrey, Outsourcing US Jobs Abroad : Why?, International Business \& Economics Research Journal - March/April 2014 Volume 13, Number 2

Peltier, H. (2020). The cost of debt-financed war: public debt and rising interest for Post9/11 war spending. Costs of War Project: Watson Institute, Brown University.

Rahayu, R. (2020). A Critical Analysis On Margaret E. Roberts (2018), Censored: Distraction And Diversion Inside China's Great Firewall. Journal of Political Issues, 1(2), 92-102. Doi: https://doi.org/10.33019/jpi.v1i2.8

Reich, R. (2016). Democrats once represented the working class. Not any more. The Guardian. Retrieved May 09, 2020, from The Guardian: https://www.theguardian.com/commentisfree/2016/nov/10/democrats-working-classamericans-us-election

Schneider-Petsinger, Marianne (2017). Trade Policy Under President Trump : Implications for the US and the World. London Chatham House: The Royal Institute of International Affairs.

Scipes, K. (2009). Neoliberal Economic Policies in the United States: The impact of globalisation on a'Northern'country. Links: International Journal of Socialist Renewal.

Tassinari, Mattia. (2019). Capitalising Economic Power in the US : Industrial Strategy in the Neoliberal Era. New York: Palgrave Macmillan

Time. (2016, June 28). Read Donald Trump's Speech on Trade. Retrieved May 07, 2020, from Time. https://time.com/4386335/donald-trump-trade-speech-transcript/

Taylor, S. J., Bogdan, R., \& DeVault, M. (2015). Introduction to qualitative research methods: A guidebook and resource. New York: John Wiley \& Sons.

The Economist. (2016, November 9). How Donald Trump thinks about trade. Retrieved May 07, 2020, from The Economist: https://www.economist.com/unitedstates/2016/11/09/how-donald-trump-thinks-about-trade

Thompson, D. (2017, Maret 23). Thomp's opulist Mirage (Trump promised to revitalize the blighted heartland. His policies will punish them.). Retrieved May 07, 2020, from theatlantic.com: https://www.theatlantic.com/business/archive/2017/03/trumpspopulist-mirage/520599/

US Census Bureau. (2019c, December). Foreign Trade - U.S. Trade with. Retrieved May 07, 2020, from Census.Gov. https://www.census.gov/foreigntrade/statistics/highlights/top/top1912yr.html

USTR. (2017, January). The United States Officially Withdraws from the Trans-Pacific Partnership | United States Trade Representative. Retrieved May 07, 2020, from 
United State Trade Representative: https://ustr.gov/about-us/policy-offices/pressoffice/press-releases/2017/january/US-Withdraws-From-TPP

Wraight, T. (2019). From Reagan to Trump: The Origins of US Neoliberal Protectionism. The Political Quarterly,90(4), 735-742. Doi: https://doi.org/10.1111/1467-923X.12709

Zucher, A. (2016, November 09). US Election 2016 Results: Five Reasons Donald Trump Won. Retrieved Maret 05, 2020, from bbc.com: http://www.bbc.com/news/electionus-2016-37918303 